\title{
THE HISTORY OF POSTOJNSKA JAMA: THE 1748 JOSEPH ANTON NAGEL INSCRIPTIONS IN JAMA NEAR PREDJAMA AND POSTOJNSKA JAMA
}

\author{
ZGODOVINA POSTOJNSKE JAME: NAGLOV NAPIS V JAMI \\ PRI PREDJAMI IN POSTOJNSKI JAMI IZ 1748
}

\author{
Stephan KEMPE ${ }^{1}$, Hans-Peter HUBRICH ${ }^{2} \&$ Klaus SUCKSTORFF ${ }^{3}$
}

\begin{abstract}
UDC 551.44(497.4 Postojna)(091) Stephan Kempe, Hans-Peter Hubrich \& Klaus Suckstorf: The history of Postojnska Jama: The 1748 Joseph Anton Nagel inscriptions in Jama near Predjama and Postojnska Jama Jama near Predjama and Postojnska Jama, Slovenia, are known for their rich body of historic inscriptions spanning over several centuries. Early explorers and visitors left names, dates and symbols. Here we present the inscriptions by the mathematician Josef Anton Nagel (1717-1794). Nagel and the painter and engineer Alois Schaffenrath (1794-1836) are the only ones that we can trace in both of the caves. Nagel visited the caves in July 1748 on order of Emperor Franz I. The inscription in Jama near Predjama is (for cave inscriptions) rather long and written in Latin, giving name, profession, cause and date of the visit, while the inscription in Postojnska Jama is rather short, giving only name and date of visit. Unfortunately the inscription in Jama near Predjama is already partly obliterated by an incautious visitor.

Key words: history of speleology, cave inscription, J. A. Nagel, Jama near Predjama, Postojnska jama, Slovenia.
\end{abstract}

Izvleček UDK 551.44(497.4 Postojna)(091) Stephan Kempe, Hans-Peter Hubrich \& Klaus Suckstorf: Zgodovina Postojnske jame: Naglov napis v Jami pri Predjami in Postojnski jami iz 1748

Jama pri Predjami in Postojnska jama sta znani po številnih zgodovinskih napisih, ki obsegajo čas več stoletij. Zgodnji raziskovalci so zapustili imena, datume in simbole. V prispevku so predstavljeni napisi matematika Jožefa Antona Nagla (1717 -1794). Le Nagla ter slikarja in inženirja Alojza Schaffenratha (1794-1836) je mogoče zaslediti v obeh jamah. Nagel je obiskal ti dve jami julija 1748, po ukazu cesarja Franca I. Napis v Jami pri Predjami, ki je za napise v jamah precej dolg, je v latinščini ter navaja ime, poklic, vzrok in datum obiska. Napis v Postojnski jami je precej kratek, le ime in datum obiska. Žal je nepazljiv obiskovalec del napisa v Jami precej poškodoval.

Ključne besede: zgodovina speleologije, napis v jami, J. A. Nagel, Jama pri Predjami, Postojnska jama, Slovenija.

\section{INTRODUCTION}

Inscriptions in caves are an important historic source. They inform about when cave visits began, when they peaked and who was visiting the caves. Specifically important are inscriptions of historically known persons. In this respect Postojnska jama is a speleohistoric treasure chest. This is, for example, completely different in case of the Baumann's Cave, Harz Mountains, which also contains hundreds of signatures, none of which so far was matched with a historically known person (for the early history of the Baumann's Cave see Kempe et al., 2004b).

\footnotetext{
${ }^{1}$ Prof. Dr. Stephan Kempe, Institute for Applied Geosciences, University of Technology Darmstadt, Schnittspahnstr. 9, D-64287 Darmstadt, Germany, e-mail: kempe@geo.tu-darmstadt.de;

2 Dipl.-Ing. Hans-Peter Hubrich, Am Langenmarkstein 31, D-64686 Lautertal;

${ }^{3}$ Klaus Suckstorff, Rosenweg 42, D-21502 Geesthacht.

Received / Prejeto: 25.04.2006
} 
Nevertheless, even in the Postojnska Jama inscriptions have not been researched extensively. An earlier paper on the pre-1818 inscriptions in the old cave (Kempe, 2003) focused mostly on the fact that these inscriptions have survived largely unaltered since they were first reported by Volpi (1821) and Hohenwart (1830, 1832a,b). Later (Kempe et al., 2004a) dealt with the inscriptions in Pisani Rov (Erzherzog Johann Grotte), specifically with those of an inscription column, initiated by Alois Schaffenrath in 1825. Most recently Kempe (2005) discussed the "Tartarus Panel" that also was established by Schaffenrath in March 1825, but that also contains the signatures of the Fercher survey party of 1833. In addition to these signa- tures, letters were published for the first time, illustrating the background of the cooperation between the administration of the Adelsberger Grotte and the direction of the mercury mine at Idria during the survey.

One of the earliest historically known persons who left inscriptions in the investigated caves was Joseph Anton Nagel (1717-1800). He visited the caves of Carniola (Krain) in 1748 and left a hand-written manuscript about his visits. Here we give pictures of both his inscriptions in Jama near Predjama and Postojnska Jama, report on their conditions and give an overview of what he had to say about the two caves.

\section{JOSEPH ANTON NAGEL}

Joseph Anton Nagel was born in Rietberg (Rittberg), Westphalia on February $3^{\text {rd }}, 1717$, and received his training as a mathematician at the "Hohe Schule von Paderborn" (Wurzbach, 1869; Schönburg-Hartenstein, 1987; Killy \& Vierhaus, s.a.). Possibly on recommendation by his country lord, Wenzel Anton Graf Kaunitz, (since 1764 Reichsfürst of Kaunitz-Rietberg) who held various offices at the court in Vienna since 1737, Nagel was able to continue his studies at the University of Vienna. After a short stay at Brünn and an administrative position at the Upper-Hungarian salt mine of Soowar, he found employment at the imperial-royal court where he worked in the administration, a position that did not challenge his profound mathematical talent.

Franz I (reigned 1745-65), the Emperor of the Holy Roman Empire of German Nation (not to be confused with Franz II, the last emperor of the Holy Roman Empire reigning 1792-1806 and who became Franz I, the Habsburgian Austrian Emperor, in which function he reigned 1804-1835) ordered Nagel to study natural curiosities, finally a task according to his talents that took him on travels throughout the Empire, first within Austria in 1747 and then to Carniola and Moravia in 1748 . Nagel spent several weeks in Carniola (Slovenia) in summer of 1748 . He duly delivered reports to the court (Nagel, 1748) that remain still largely unpublished (see Shaw, 1992). At around 1760 Nagel became a mathematician of the Habsburgian court and teacher of Erzherzog Karl Joseph and travelled abroad to France, England, the Netherlands, Hungary and Tyrol. On initiation by Maria Theresia he began to work on a map of the city of Vienna (1770 and 1779) and its suburbs (Ground plan of the Imperial-Royal Residence City Vienna, its suburbs and neighbouring towns) which was published as a copper etching in 1780/81. He also produced a map of the inner city of Vienna in 1774. Furthermore, he served as the director of the physical cabinet from 1770 until after 1790. In 1775 he was appointed director of the Philosophical Faculty of the University of Vienna, a position he held until his retirement at around 1790. Nagel died in Vienna on May 6 $6^{\text {th }}, 1794$.

\section{HIS REPORTS}

The reports delivered by Nagel were hand-written in Current, the handwriting for official documents. The manuscripts about three of his early excursions were not published at the time (see Shaw, 1992). These are the descriptions of the Ötscher Mountain in 1747, about his travel to Crain and Moravia in 1748, and about his journey to Holic/Hungary. His account of the earthquake of 1768 was published in print.
During his Crain and Moravia excursion Nagel spent several weeks in Slovenia in summer of 1748. The manuscript related to his observations has 97 pages and 22 figures. It is kept at the Austrian National Library at Vienna (MS N. 7854). We have now transcribed it entirely, planning its publication in full length. It is baroquely titled: 


\author{
Beschreibung \\ deren \\ Auf allerhöchsten Befehl \\ Ihro Röm: Kayl: und Königl: \\ Maytt: FRANCISCI I \\ untersuchten, in dem Herzogthum \\ Crain befindlichen Seltenheiten \\ der Natur
}

(Description of the curiosities of nature of the Herzogtum Crain studied by highest order of his Roman Emperial and Royal Majesty, Franz I.)

In this text we find many references to karst and caves, among them the "Lueger Höhle" (Jama near Predjama) and the "Adelsberger Grotte" (Postojnska Jama).

In the beginning of his report, Nagel clarifies some of the tales in VALVASOR's epic chronic (1689) that, as he explains, rest on wishful thinking, unproven hear-say and superstition but not on reality. In many cases he corrected doubtful passages by his own observations or by factual logic. He lists the following examples of distorted facts:

- catching crabs by whistling;

- hunting „Pilliche“ (i.e. Bilche, Siebenschläfer, engl. dormouse, Glis glis) with boots and coats spread out on the ground;

- attracting leeches in Cerkniško jezero by singing;

- making „Heimchen“ (i.e. the house cricket, Acheta domestica) appear by magic spells;

- cemeteries on the top of Beuscheza Mountain and on the Steiner Alps;

- the occurrence of eye- and featherless ducks after floods in Cerkniško jezero that can see and fly after two weeks again (which probably is a distorted early account of the endemic Proteus anguinus);

- that the condensed fog drifting from caves represents devilish smoke.

He reacted to such absurdities with the appeal that the authors should refrain from pleasing eulogies and distorting flourishes in "history books". Rather they should describe the reality and stick to truth.
Nagel deals with famous Cerkniško Jezero in a great detail. Among other facts he describes:

- Changing water levels - up to complete dryness - and their dependence on precipitation;

- the existence of numerous connections between the lake bottom and the conduits in the karst mountains;

- artesian bursts of water after torrential rains;

- water-level-limiting ,swallow holes“;

and he discusses thoughts about the connectivity of the water courses above and below ground.

The observed interdependencies and the conclusions drawn from them are finally packed together into a logical hydraulic model including abstracted inputs and outputs and water-level-depending discharges. Furthermore he postulates underground connections between caves and Cerkniško Jezero in the order: Cerkniško Jezero - Cave of St. Canzian (Rak valley, Zelške Jame) - Pivka - Adelsberger Grotte - Kleinhäusler Grotte - Untz.

$\mathrm{He}$ deals with the phenomenon of noisily flowing water masses in karst cavities as well as with the thunder of so called "weather holes" (Hexenlöcher, Coprniška Jama). He continues to describe his observations in the Karst, specifically about its caves, sketching their accessibility, spatial dimensions, length, divisions into compartments and remarkable flowstone formations.

Nagel reports about the cave at St. Canzian (Rak valley, Zelške Jame), the "Gotscheer" caves (Kočevje), the three weather holes at Ober-Gurck (Krka), the curious spring at Ober-Laibach (Vrhnika), the cave at Planina / Kleinhäusler Grotte as the source of river Untz (Unica) (Planinska Jama), the Adelsberger Höhlen (Postojnska Jama), the Magdalenen-Grotte (Črna Jama), the Lueger Höhle (Jama near Predjama), the cave at St. Servolo, the cave at Cornial (Vilenica), and the cave at Sloup in Moravia and the huge Macocha sinkhole.

These descriptions are flanked by reports about other natural curiosities, such as a special nut tree (i.e. a tree with an extremely short vegetation period), the Dattili del Mare (marine bivalves that can drill into limestone) and a waterfall at Freistritz in Ober-Crain.

\section{NAGEL'S REPORT „VON DER LUEGER HÖLE“}

Nagel did not find the Castle of Lueg, now a world-wide known tourist attraction, very attractive. He describes it as being built into the niche of the vertical wall above the cave entrance (Jama near Predjama). About $70 \mathrm{~m}$ behind the upper cave entrance a deep well is found that always contains good water. This cave served, according to legend, Erasmus Lueger, who was accused of having murdered Marshall von Pappenheim, of committing robbery and treason. This stronghold could not be conquered for a long time. It was provisioned through a four mile long secret passage from the Birnbaum Forest (Hrušica). Nagel did not find this passage and discredited it as a pure invention. The access to the main cave, across a bridge and $30 \mathrm{~m}$ below the castle, was walled up at the time of Nagel. Nagel was able to explore about $800 \mathrm{~m}$ of passages. He found several sections of different character: stretches 
with a loamy floor without flowstone, low crawling passages, two white flowstone pyramids, and „rare“ figures of flowstone on the wall reminding of trees and forests. He observed a strong air current, emanating from a hole at the end of the cave, and concluded that there must be more passages; and he saw the many inscriptions of names that people had left there prior to his visit.

\section{NAGEL'S REPORT „VON DER ADELSPERGER HÖLEN“}

In his paragraph about Postojnska jama Nagel states that the cave consists of four cavities. Into the lower, left one, the "Poyckfluß" (Pivka) sinks. Nagel makes the first map of the cave (one of the earliest ever made) and describes in the text the individual cave sections accessible at the time, noting length, situation, branches, special formations, flowstone figures etc.. $40 \mathrm{~m}$ behind the entrance there are remains of a wall from the time when the locals hid in the cave from raiding Turks. He cites the opinion and accedes with it that the Pivka reappears about $5 \mathrm{~km}$ further north from Planinska Jama as the "Untz" river (Unica). Again, just as in the preface to the manuscript, Nagel refutes VALVASOR, who related that a ghost haunts the first section of the underground water course and that it would turn the neck of any intruder, simply by stating that he himself and his party emerges from the cave with "straight necks". Nagel explains the occurrence of fishes in the cave streams with the changes in water level or discharge volume. For a 70 year old inscription Nagel calculates the flowstone growth rate (Pag. 46/2; see also Shaw, 1992). With this rate at hand, he estimates that the large columns in the Cave of Cornial (Vilenica) with six "Schuh" diameter must have taken 90,720 years to grow. But instead of casting doubt on the static Christian date of creation - calculated by Anglican Archbishop James USSHER (born $4^{\text {th }}$ of January, 1581, in Dublin; died, $21^{\text {st }}$ of March, 1656, in Reigate, Surrey) to have happened on $23^{\text {rd }}$ of October $4004 \mathrm{BC}$ - he shies away from the possible consequences and just states: „Da aber seit der Sintflut nur 5696 Jahre verflossen seien, müssen sich Irregularitäten ereignet haben" (But because 5,696 years passed since the deluge, there must have been (other) irregularities"). Here Nagel makes a mistake: Ussher actually dated the deluge to $2501 \mathrm{BC}$ i.e. the year 1748 should have been 4249 after the deluge and not 5696 . His date would (5696-4004-1748) place the deluge at 56 years after the creation of earth....

Nevertheless he questioned the accepted dogma in the following sentence (possibly with a twinkle in his eyes) by saying: „Doch ist gewi $\beta$, daß sie (die Anwachsung des Tropfsteins) sehr lang zugehe (benötige), weil sonst die Höhlen in gar kurzer Zeit mit Tropfstein durchgehend angefüllet werden, folglich den Wässern zu ihrem Lauf kein Raum mehr übrig bleiben werde". (But it is for sure that it (the growth of the stalagmite) takes a long time, because otherwise the caves would be filled completely in a short time and the waters would not have space for their passage). Nagel's report was written in 1748 and the time was ripe for some critical assessment on the age of the Earth. Only seven years later (1755) IMMANUEL KANT challenged the biblical view of the world in his book "Allgemeine Naturgeschichte und Theorie des Himmels" and in 1780 JAMES HUTTON laid the foundation in his "Theory of the Earth" to exchange the biblical dating for a more scientifically founded calculation of the age of Earth.

So far, not all of the pictures of Nagel have been republished, among others, Shaw (1992) reprinted a few of the pictures which accompany the reports including the first map of the old Adelsberger Grotte. It is an amazingly correct ground view of the frontal part of the cave, giving all at the time known passages in due proportions and directions.

\section{NAGEL'S INSCRIPTION IN PREDJAMSKI JAMA}

Probably the most important and certainly the longest inscription in Jama near Predjama yet documented was left by Nagel in Latin (Fig. 1). It is located on the right wall (looking in direction of the guided tour) in the "NamePassage" (Imenski rov), about $1 \mathrm{~m}$ above the floor and just beyond the "Bear Hole" (Medvedja Luknja). We took a picture of it during a guided tour on $19^{\text {th }}$ of July, 2005.
It is a small inscription written with pencil. Because the common clay-graphite pencil had not yet been invented, the pencil used by Nagel was most probably either a metal pencil (silver, lead or tin) or a piece of sharpened mineral graphite. According to the German Jama near Predjama guide (Habe, 1981; p. 43) the inscription reads as follows: 


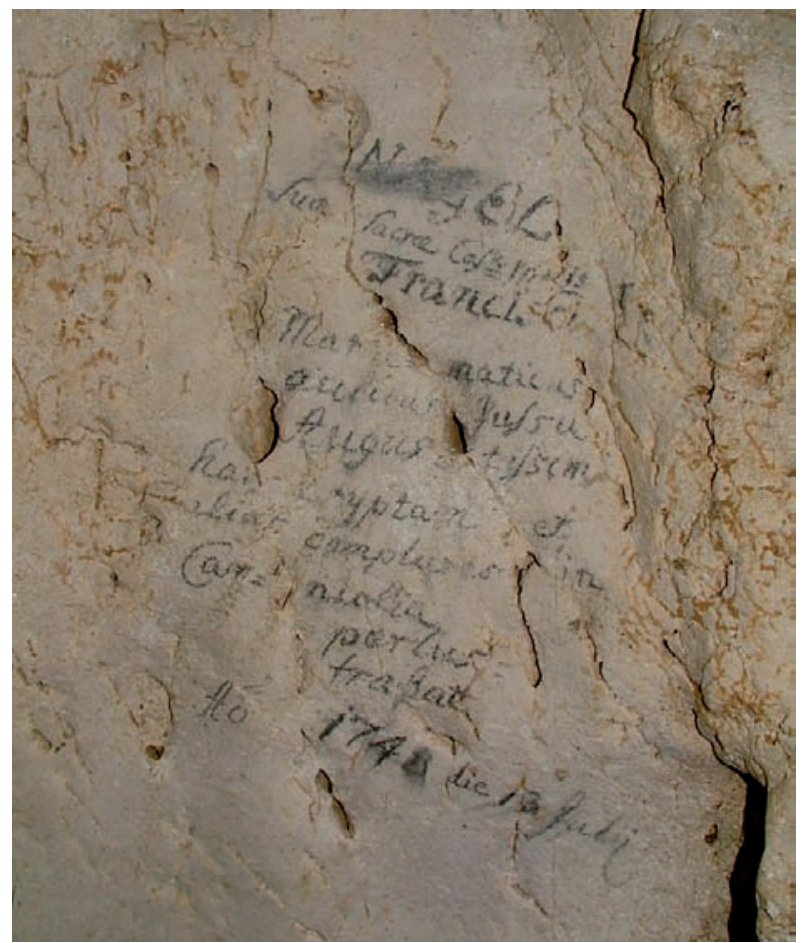

Fig. 1: Photograph of Nagel's inscription in Jama near Predjama (Photo by S. Kempe).

NAGEL

suae sacrae Caesareae Majestatis (abbreviated)

Franci. I

Mathematicus

aulicus Jussu

Augustissimi

hanc cryptem et

alias complures in

Car=niolia

perlus-

trabat

A//o 1748 die 13 Julii

That is translated:

His Holy Imperator and Majesty

Franz I

Mathematicus

on order of his

highest (lord)

(has) this crypt and

others many

in Carniola (Kärnten)

investigated

Anno 1748 day 13 July

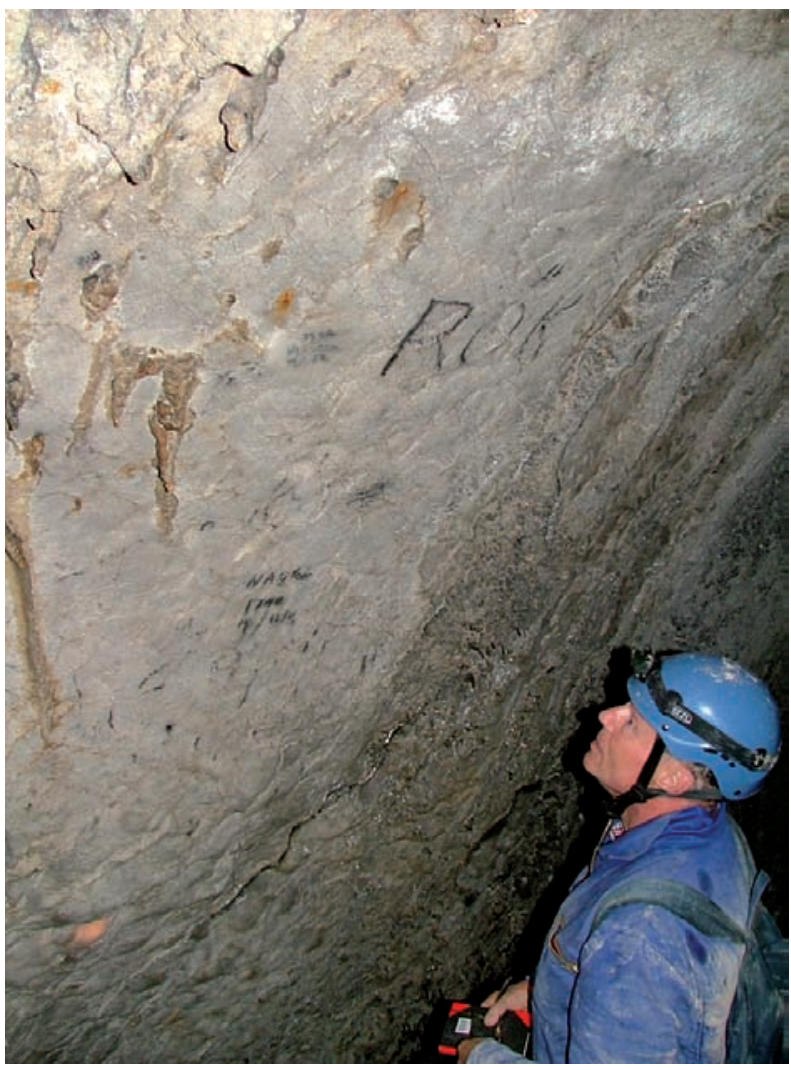

Fig. 2: Situation of the Postojnska jama Nagel-Inscription (H.P. Hubrich for scale) (Photo by S. Kempe).

Habe (1981) reports that the inscription had first been identified by the Coleopterologist Egon Pretner. Habe (1981; Inset Plate 14) also published a color picture of the inscription. It is, however, too small to read details clearly. Comparing Habe's picture with our picture, it is clear that the inscription has been damaged in the meantime: The letters NAG from Nagels's name suffered a substantial smear. Also the " 8 " in " 1748 " appears somewhat blurred. Obviously someone touched the inscription accidentally while pointing at the lines. If it would have been an intentional damage, then the entire inscription could have been blurred with one palm stroke.

A few centimeters above Nagel's name there is another line with about five to six pencil-written letters, all illegible. If this line is connected with Nagel's inscription cannot be said with certainty. 


\section{NAGEL'S INSCRIPTION IN POSTOJNSKA JAMA}

Nagel also left his name in Postojnska jama. Habe already mentioned this (1986, p.14) but fails to give its position. On July $21^{\text {st }}$, we visited the old gallery in Postojnska jama in search of Fercher survey team inscriptions (1833; see Kempe, 2005). We found Nagel's signature on the $45^{\circ}$ sloping ceiling ca. $50 \mathrm{~m}$ from the access ladder (Fig. 2). It occurs - with a few other signatures (termed Old-Cave Panel 1) - at a place where there is no substantial speleothem growth. The signature is small and consists only of three lines (Fig. 3):

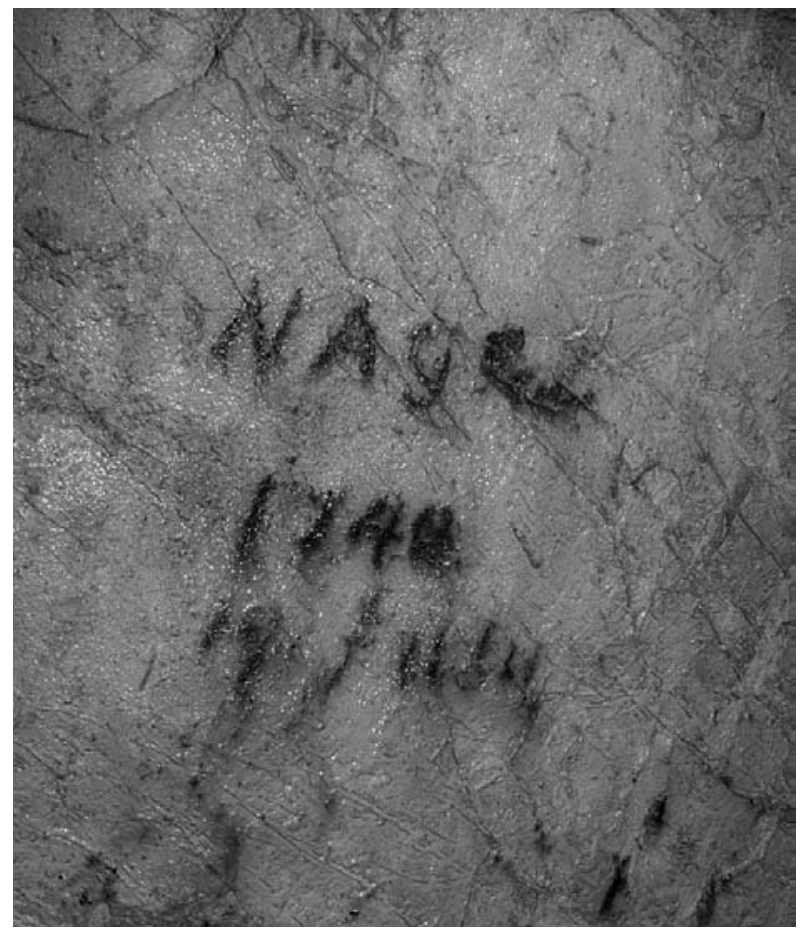

Fig. 3: Photograph of Nagel's inscription in Postojnska Jama (Photo by S. Kempe).

\section{NAGEL \\ 1748 \\ 19 Julii}

In both inscriptions Nagel uses only his Family name, spelled in capitals (if one accepts the last three letters of the Postojna inscriptions as capitalia). In Postojna he also uses printed letters for the month, while in Jama near Predjama we find the month (as well as the other text) written in a fluent handwriting. Both times the name of the month is given in its Latin form. The Postojna inscription is, however, much more blurred than the Predjamski jama text. In Postojnska Jama probably the wall was not as dry as in Jama near Predjama and the "ink" apparently started to diffuse into the intergranulars of the underlying rock surface. Tiny white specs have overgrown the writing in addition and a thin transparent veneer of flowstone has covered them. The nature of the pen, with which was written cannot be assessed with certainty. In any case the reading of the inscription is much assisted by the knowledge of who made it and when it was made. The year and the name of the month can be identified clearly at least once one knows that Nagel visited the area in July 1748. The exact date of the month is, however, illegible. Habe (1986, p. 14) assumed it is the 13th, but that is highly unlikely. We rather suggest the $19^{\text {th }}$ as being the correct reading. That it cannot be the $13^{\text {th }}$ arises from the fact, that Nagel then should have visited both Postojna and Jama near Predjama on the same day. Even more so, he should have produced the quite accurate map of Postojnska jama and explored Jama near Predjama extensively. All this is not very likely to have happened in one day. Alternatively the second numeral in the day could be a " 4 " making it the $14^{\text {th }}$. In any case Nagel seems to have visited first Jama near Predjama, before he worked in the old Adelsberger Grotte.

\section{CONCLUSIONS}

The well dated Nagel inscriptions are part of a much larger body of inscriptions. The inscriptions tell us something about the frequency of visits. In Jama near Predjama there are many inscriptions dating from the $18^{\text {th }}$ century. This is in striking contrast to the old cave of Postojna. There we only found two inscriptions out of ca. 250 documented by us as yet dating from the $18^{\text {th }}$ century. Apart from Nagel, only one visitor signed during that century and that was much later, i.e. in the year 1795. The last date before Nagel's visit was 1699, making Nagel's date the only one within almost a hundred years!
Nagel's inscriptions are singular in that sense that they are the oldest of a person known for his speleological accomplishments. It is not the oldest of a historically known person because in Jama near Predjama we find signatures of the Cobenzl family, the owners of the Predjama Castle that probably predate Nagel's signature.

Nagel is also not the only person who left his name in both caves: Alois Schaffenrath (1794-1836), famous for his drawings of Postojnska jama (published by Hohenwart, 1830, 1832a,b, and in his guide to the cave, Schaffenrath, 1834) left his name also in both caves (Figs. 4 and 5) 


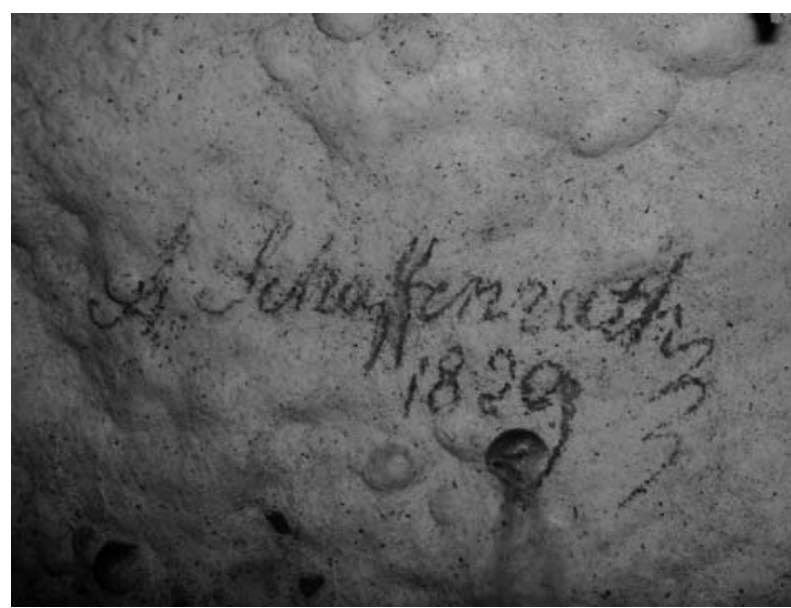

Fig. 4: Photograph of Aloys Schaffenrath's signature in the old cave of Postojnska jama (Photo by S. Kempe).

as we now discovered. Above Schaffenrath's signature the name "Jac. Vidmar" is found in the same handwriting. Jacob Widmar (spelled German) was one of the workers present, when Luka Čeč discovered the main passage in Postojnska jama and who left a written statement about the circumstances of this discovery. It was reproduced by Schmidl (1854) and is discussed in detail by Kempe et al., (2004a). Obviously Vidmar and Schaffenrath visited

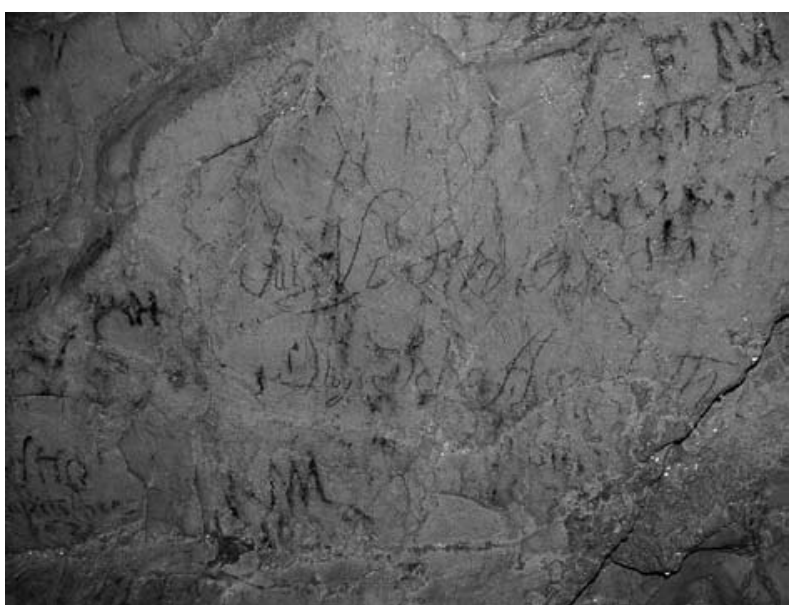

Fig. 5: Photograph of Jacob Vidmar's and Aloys Schaffenrath's signatures in Jama near Predjama at the end of the historic passage (Photo by S. Kempe).

Jama near Predjama together. Unfortunately they did not note the date of their visit.

Studying cave inscriptions yields new information about the history of the cave, its explorers and visitors. We are working now on a data bank documenting all of the inscriptions in the old cave of Postojna

\section{ACKNOWLEDGEMENTS}

We thank Dr. Tadej Slabe for organizing the visit to Postojnska jama and the administration of the cave for allowing us to visit the cave beyond the tourist trails. Helena Vičič guided us into Jama near Predjama on $19^{\text {th }}$ July, 2005, and
Leon Drame from the Karst Research Institute accompanied us into Postojnska jama on $21^{\text {st }}$ of July, 2005. English was improved by Dr. M.S. Werner, Hilo, Hawaii. 


\section{REFERENCES}

Habe, F., 1981: Predjama, das Schloss und die Höhle, 1. Aufl..- Höhle von Postojna, 50 pp, 16 Tafeln.

Habe, F., 1986: The Postojna Caves and other Tourist Caves in Slovenia, $4^{\text {th }}$ ed. - Postojnska jama, Postojna, 83 pp, 11 Plates, 1 folded map.

Hohenwart, F. Graf von, 1830, 1832a, 1832b: Wegweiser für die Wanderer in der berühmten Adelsberger und Kronprinz Ferdinands-Grotte bey Adelsberg in Krain; als Erklärung der von Herrn Aloys Schaffenrath, k.k. Kreis-Ingenieur in Adelsberg, gezeichneten Ansichten dieser Grotte. - Wien, J.P. Sollinger, 3 Vol., $16+9+14$ pp. and 21 copperplates (Reprint 1978: Šajn, S., ed.; Introduction: Habe, F. \& Šlenc, J.: Postojnska jama; 1. ed., Postojnska Jama THO; Postojna; 32 pp Introduction, folio).

Kempe, S., 2003: Die alten Inschriften der Adelsberger Grotte /Postojnska Jama. - Die Höhle, 54(2): 36-44.

Kempe, S., 2005: The inscriptions of the Tartarus Panel and the 1833 Fercher-survey, Postojnska jama. - Acta Carsologica, 34/1 (13): 221-235.

Kempe, S., I. Bauer, H. Dirks, \& H.-V. Henschel 2004a: Schaffenrath's inscription column in Pisani rov, Postojnska jama. - Acta Carsologica, 33/2: 299312.

Kempe, S., B. Dunsch, K. Fetkenheuer, G. Naumann \& F. Reinboth, 2004b: Die Baumannshöhle bei Rübeland/Harz im Spiegel der wissenschaftlichen Literatur vom 16. bis zum 18. Jahrhundert: Lateinische Quellentexte. - Braunschweiger Naturkundliche Schriften, Bd. 7, Heft 1, Okt. 2004: 171-215.

Killy, W., \& R. Vierhaus, (eds.), s.a. [ca. 1990]: Deutsche Biographische Enzyklopädie Bd. 7, (May-Pleßner). - Wissenschaftliche Buchgesellschaft, Darmstadt, 695pp (Nagel see p. 335).
Nagel, J.A., 1748: Beschreibung deren auf allerhöchsten Befehl Ihro Röm. Kayserl. und königl, Maytt. Francisci I. untersuchten in dem Herzogthum Crain befindlichen Seltenheiten der Natur. - Vienna: Nationalbibliothek, MS N. 7854, ii +97ff.

Schmidl, A., 1854: Die Grotten und Höhlen von Adelsberg, Lueg, Planina und Laas, Text and Atlas. - Wilhelm Braumüller, Wien, 316 pp, 15 Plates.

Schaffenrath, A., 1834: Beschreibung der berühmten Grotte bei Adelsberg in Krain. - I. Edlen v. Kleinmayr, Laibach, 32 pp., 2 Lithographs.

Schönburg-Hartenstein, J.; 1987: Josef Anton Nagel - ein Direktor des physikalischen Kabinettes, Verlag der österreichischen Akademie der Wissenschaften, Wien.

Shaw, T.R., 1992: History of Cave Science, the Exploration and Study of Limestone Caves, to $1900 .-2^{\text {nd }}$ ed., Sydney Speleological Soc., Broadway, New South Wales, Australia, 338 pp.

Valvasor, J.W., 1689: Die Ehre des Herzogthums Crain: Das ist: Wahre, gründliche, und recht eigendliche Belegen- und Beschaffenheit dieses, in manchen alten und neuen Geschicht-Büchern zwar rühmlich berührten, doch bishero nie annoch recht beschriebenen Römisch-Keyserlichen herzlichen Erblandes, Bd. I-IV. - Wolfgang Moritz Endter, Buchhändler in Nürnberg, Laybach.

Volpi, G. de, 1821: Über ein bey Adelsberg neuentdecktes Paläotherium. - Maldinische Schriften, Triest, 31 pp., 2 Plates.

Wurzbach, C.v., 1856 - 1891: Biographisches Lexikon des Kaiserthums Oesterreich; 60 Bände; Wien, Verlag der Universitätsbuchdruckerei von L.C. Zamarski und später Druck und Verlag der k.k. Hof- und Staatsdruckerei. 